\title{
Caring for cancer patients facing death: nurse's perception and experience
}

\author{
Cuidando do paciente com câncer diante da morte: percepções e vivências do enfermeiro \\ Cuidado del paciente con cáncer a punto de morir: percepciones y vivencias del enfermero
}

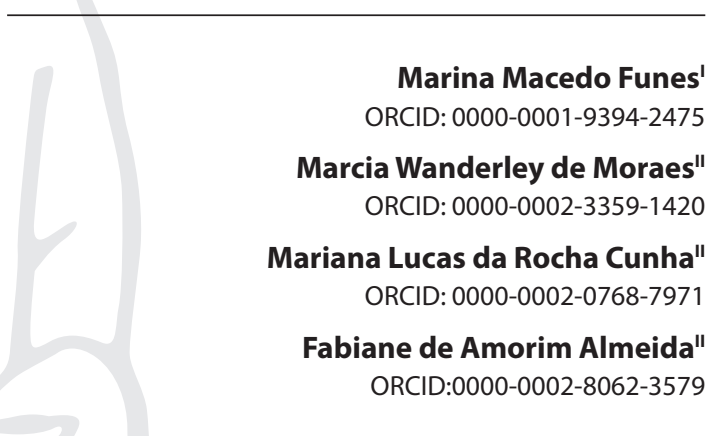

'Hospital e Maternidade SEPACO. São Paulo, São Paulo, Brazil. "Faculdade Israelita de Ciências da Saúde Albert Einstein. São Paulo, São Paulo. Brazil.

How to cite this article: Funes MM, Moraes MW, Cunha MLR, Amorim FA. Caring for cancer patients facing death: nurse's perception and experience. Rev Bras Enferm. 2020;73(Suppl 5):e20190686.

doi: http://dx.doi.org/10.1590/0034-7167-2019-0686

Corresponding author:

Mariana Lucas da Rocha Cunha E-mail: mariana.cunha@einstein.br

EDITOR IN CHIEF: Antonio José de Almeida Filho ASSOCIATE EDITOR: Fátima Helena Espírito Santo

Submission: 12-17-2019

Approval: $04-27-2020$

\begin{abstract}
Objective: To know the experiences and perceptions of nurses who care for dying cancer patients. Method: A descriptive, qualitative study, developed in a private hospital in Sao Paulo, with a total of nine nurses, aged between 24 and 46 years old, who participated in a semi-structured interview. Results: Through Bardin's Content Analysis, three categories were highlighted: Death as a natural process and the final stage of the life cycle; Although it is difficult, it is important to get emotionally involved with dying patients and their family; and Reflecting on their experiences in the care of dying patients and their family. Final Considerations: The nurses' experiences and perceptions of the death of cancer patients showed the professional's involvement and feelings of anxiety and anguish. Adopting effective strategies to address people who are suffering, in the context of the study, can provide subsidies that will guide clinical practice in health.

Descriptors: Nurses; Neoplasms; Death; Attitude to Death; Patient Care.
\end{abstract}

\section{RESUMO}

Objetivo: Conhecer as vivências e percepções dos enfermeiros que cuidam de pacientes com câncer que estão morrendo. Método: Pesquisa descritiva, qualitativa, desenvolvida em hospital particular de São Paulo, com nove enfermeiros, entre 24 e 46 anos, que participaram de uma entrevista semiestruturada. Resultados: Por meio da Análise de Conteúdo de Bardin, evidenciaram-se três categorias: Entendendo a morte como um processo natural e a etapa final do ciclo de vida; Sendo importante, embora difícil, envolver-se emocionalmente com o paciente que está morrendo e sua família; e Refletindo sobre suas vivências no cuidado do paciente que está morrendo e sua família. Considerações finais: As vivências e percepções dos enfermeiros diante da morte de pacientes com câncer evidenciaram o envolvimento do profissional e os sentimentos de ansiedade e angustia. Adotar estratégias efetivas para abordar pessoas em situação de sofrimento, no contexto da pesquisa, pode fornecer subsídios que nortearão a prática clínica em saúde.

Descritores: Enfermeiras e Enfermeiros; Neoplasias; Morte; Atitude Frente a Morte; Assistência ao Paciente.

\section{RESUMEN}

Objetivo: Conocer las vivencias y percepciones de los enfermeros que cuidan de pacientes con cáncer a punto de morir. Método: Se trata de una investigación descriptiva, cualitativa, llevada a cabo en un hospital particular de São Paulo mediante entrevista semiestructurada entre nueve enfermeros de 24 a 46 años de edad. Resultados: A través del Análisis de Contenido de Bardin se destacaron tres categorías: la comprensión de la muerte como un proceso natural y la etapa final del ciclo de la vida; el envolvimiento emocional con el paciente moribundo y su familia, importante, pero difícil; la reflexión sobre las vivencias en el cuidado del paciente moribundo y su familia. Consideraciones finales: Las vivencias y percepciones de los enfermeros sobre la muerte de los pacientes con cáncer pusieron de relieve la implicación y los sentimientos de ansiedad y angustia del profesional. La adopción de estrategias eficaces para atender a las personas en situación de sufrimiento, en el contexto de la investigación, puede proporcionar subsidios que orienten la práctica clínica en materia de salud.

Descriptores: Enfermeras y Enfermeros; Neoplasias; Muerte; Actitud Frente a la Muerte; Atención al Paciente. 


\section{INTRODUCTION}

Oncological problems have a great worldwide incidence, reaching people of all genders, ages, cultures and socioeconomic situations. Cancer is the name given to diseases that have disorderly growth of cells, and then an invasion of tissues and organs. This disordered growth is characterized by aggressive and uncontrolled cells, leading to the formation of tumors that can spread to other parts of the body. The International Agency for Research on Cancer (IARC) estimates that, worldwide, one in five men and one in six women will develop cancer during their lifetime ${ }^{(1-2)}$. Estimates from Brazil's National Institute of Cancer (INCA), for 2018-2019, indicate the occurrence of 600 thousand new cases of cancer, with a total of 190 thousand deaths, corresponding to the second leading cause of death in Brazil ${ }^{(3)}$.

The diagnosis and treatment of cancer can impair in a person's functional capacity, due to the impact on their ability to perform daily activities and social relations, also interfering in financial aspects $^{(4)}$. Even with the advancement of medicine with regard to the treatment of terminal illnesses, neoplasia is almost always associated with a death sentence by the population. It is a moment of life that nobody wants to go through, whether in relation to themselves or to relatives and friends ${ }^{(5)}$.

The interpretation of the meaning of having cancer is influenced by culture. Thus, the professional responsible for the care of people with cancer also suffers interference from the perceptions and meanings attributed by them related to death and getting sick ${ }^{(6)}$. The care for cancer patients requires the nurses not only to know the disease, but also the ability to deal with their feelings and emotions when dealing with this situation, seeking to offer a more humanized assistance ${ }^{(7)}$.

Humanization in nursing is related to the professional's ability to perceive the patients individually according to their needs. From the patients' perspective, humanized care occurs when the nurse communicates properly, giving information about the diagnosis, treatment and prognosis, in addition to promoting their autonomy. It is the role of this professional to try to minimize the suffering of patients during hospitalization, respecting their expectations, anxiety, fears and insecurities ${ }^{(8)}$.

Dealing with suffering, anguish, sadness and fears that may arise during the care and death process leads nurses to adopt coping strategies that can cause psychological repercussions and suffering, reflecting on their professional performance ${ }^{(9-10)}$.

This study aims to investigate the experiences of nurses in the process of caring for dying cancer patients, in an advanced stage of the disease. Thus, some questions guided the study: What is the meaning of death for nurses who care for cancer patients?; How was their first experience in caring for a dying patient? What is it like to care for dying patients?

Understanding the way nurses face suffering when caring for dying cancer patients and how these experiences impact their lives is essential for health institutions to define strategies, in order to support them, promoting well-being and mental health of these professionals.

\section{OBJECTIVE}

To know the experiences and perceptions of nurses who care for dying cancer patients.

\section{METHOD}

\section{Ethical Aspects}

Data were collected in the first half of 2017, after approval of the project by the Research Ethics Committee of the principal institution, as well as after authorization granted by the manager of the center where the collection occurred. Data were collected by the first author, under the guidance and monitoring of the other authors.

The first author was trained in conducting interviews in qualitative studies before data collection, following all ethical aspects that involve researches with human beings. It should be noted that there was no relation established between researchers and respondents prior to the study.

Participants were instructed on the objectives of the study, their rights, benefits and research terms. After confirming their agreement to participate in the study, they signed the Informed Consent Form (ICF).

The researchers are committed to use the data exclusively for this study and to keep the identification of the participants confidential, as established in the Researches Commitment Term. Thus, the name of each professional was replaced by the letter " $E$ ", followed by an Arabic numeral. The requirements of Resolution $466 / 2012$ of the National Health Council (CNS) were followed ${ }^{(11)}$.

\section{Type of study}

This is a descriptive study, with a qualitative approach, based on the precepts of discourse analysis, in line with the study design according to the recommendations of the Consolidated Criteria for Reporting Qualitative Research (COREQ) ${ }^{(12)}$.

For data analysis, we used Bardin's content analysis technique, characterized by a set of communication analysis strategies that try to identify what is being said about a specific topic, through systematic and objective procedures ${ }^{(13)}$.

\section{Study Setting}

The study was carried out in the oncology unit of a private, extralarge hospital, located in the Southern Area of the city of Sao Paulo, Brazil. The unit assists, on average, 28 patients per month, with solid and hematological tumors, with leukemias and lymphomas being the medical diagnoses most frequently identified in these patients.

\section{Data source}

The sample had a total of nine professionals, selected by convenience, who worked with assistance and agreed to participate in the study. Those who did not experience care for dying cancer people until the time of data collection were excluded. All invited nurses agreed to participate in the study. The sample size was defined during data collection, which ended when the information obtained was enough to understand the studied situation.

\section{Data collection and organization}

Face-to-face semi-structured interviews were the selected data collection strategy, being carried out individually with each 
participant in a private room, in their workplace, as chosen by them. The interviews were scheduled according to the availability of the interviewees, being recorded on audio and later transcribed for analysis. The duration of the interviews was on average 5 to 8 uninterrupted minutes, which were conducted based on a script made by the authors and consisting of two parts: information about the professionals' profile and questions about their experience in caring for dying cancer patients. Each participant was interviewed once, receiving no feedback from the interview.

\section{Data analysis}

After the transcription of the interviews, we did a comprehensive reading of the entire reported content, in order to obtain an initial perception of the analyzed material. After that, we did successive readings, making it possible to note the significant excerpts, which were highlighted in the text.

These excerpts received codes, necessary for their grouping in the categorization process. Initially, the selected excerpts were grouped based on the thematic differences that emerged. In the second stage, the other highlighted excerpts started to be grouped by similarity of content.

Then, considering the approximation of theoretical assumptions with the empirical data, the synthesis of the speeches was made. The data were coded and analyzed by the first researcher and subsequently validated by two researchers who had experience in qualitative studies.

\section{RESULTS}

\section{Knowing a little more about the study participants}

Most of the nurses interviewed were female (77.7\%), aged between 24 and 46 years old, with an average of 32 years old. Regarding professional training, all of them had completed specialization courses, most of them in the oncology area (77.7\%). As for religion, Catholicism (44.5\%) and spiritism (22.2\%) stand out, followed by Christianity and Adventism (11.1\%), in addition to people who declared themselves without religion (11.1\%).

\section{Understanding the experiences and perceptions of nurses who care for dying cancer patients}

From the analyzed data, three categories emerged: Death as a natural process and the final stage of the life cycle; Although it is difficult, it is important to get emotionally involved with dying patients and their family; and Reflecting on their experiences in the care of dying patients and their family.

\section{Category 1: Death as a natural process and the final stage of the life cycle}

The speeches show what death represents for the nurses, considering their professional and personal experiences. Death is understood as a transformation moment, which involves the person's transition to another dimension.

... For me, dying means only a transition to another dimension. (E1)
... I see death as a process of disembodiment, where the spirit continues to live. (E2)

Nurses seek support in religion to understand death, often going beyond the precepts of their own religion, when they appropriate other religious philosophies to expand their understanding about the subject. They believe that life continues after death, everything is already defined in advance by destiny and everyone should prepare themselves for the moment of their death.

Look, I'm Catholic, but actually I also like spiritism. So, I think that life continues [after death]. I think the person had to go through this... the disease. The person had to go through that process and, in my opinion, death is an evolution. You will go to another phase. So, for me, [life] does not end. (E8)

I'm baptized in Catholicism, however, today I follow the principles of spiritualism a lot. I have a very developed and strong belief. Therefore, dying is nothing more than a part of the life process. It's something completely natural and necessary, we should all be clearly aware that, surely, one day it will happen to us. And we should prepare ourselves for that. I think death is part of our evolution process as a human being. (E9)

For the professionals, death is the final stage of a cycle that all human beings must go through and that does not end with the finiteness of the body, representing part of a natural process of life, as important as birth, even though it is difficult to understand it.

... I think it means closing a cycle, but it's not necessarily a bad thing. I think it's a process as important as birth. And I think we're very lucky to be part of that. (E4)

... In my opinion, death is an evolution. You'll go to another stage. So, for me, it doesn't end. (E8)

Dying is nothing more than a part of the life process, it's something completely natural and necessary, we should all be clearly aware that it will surely happen to us one day and we should prepare ourselves for it. I think that death is part of our evolution process as a human being. (E9)

However, for one of the nurses, death is conceptualized as a biological event, involving physiological processes that lead to cell death and interruption in the functioning of body systems. Another nurse also associates death with the cessation of bodily activities and the idea of a permanent sleep state.

$H \mathrm{~mm}$... [pause] ... it's the interruption of brain functions, due to the lack of nutrients and oxygen to keep neurons alive. (E3)

It's a sleep in which the person doesn't wake up, a cessation of the things of this world, of living, eating. (E7)

Nurses reflect on their own death as a human being and its perspective as a motivating factor for individuals to achieve their goals in the world, while they are alive.

Death... we have to know that one day we'll die. One day we'll die and it will end. Because if we don't have a perspective that our life 
is going to end, we wouldn't do things willingly... we would have a lot of time to do it. So, it's good that everything has to have a limit... life is one of them. (E5)

\section{Category 2: Although it is difficult, it is important to get emotionally involved with dying patients and their family}

The professional's involvement with dying cancer patients and their family is essential, considering that the evolution of the disease, in most cases, is long and causes a lot of suffering for the patients and also for their family. In oncology, the difficulty in separating the emotional from the professional is evident in the reports.

Assistance to patients in the death process is psychologically/ emotionally complicated, since we are present in most of the cases from the discovery [of the disease] to death. (E1)

Often distressing [caring for dying patients]. Not only because of the patient's situation that comes from long-term suffering, but more strongly related to the non-acceptance of their family members. (E3)

The most difficult thing of being a nurse is being able to separate the professional from the personal and, at the same time, provide comfort for the patients and their family during this process. (E2)

Nurses emphasize the importance of their involvement in care during the death process, despite not being a member of the patients' family, providing comfort at that moment, regardless of the expected prognosis for that case.

It's really important in the patients' life [taking care of them when they are dying], since you're a stranger trying to give the greatest comfort, they need at that moment ... Sometimes, not even the family member can provide comfort to someone [in the family] when the patient dies. (E5)

You have to take care of them with the same sensitivity, the same way you would take care of a patient who has a good prognosis, giving the same quality of comfort and care. It means taking care of them in the same way, giving all the comfort. (E8)

When caring for a patient with no possibility of cure, the moment of death is always very difficult for nurses, according to the interviewed professionals, who seek strategies to make this moment less painful, such as mentalizing positive thoughts, praying or making the environment as peaceful as possible. Promoting comfort, maintaining their commitment and respect for others also help professionals to deal with this situation.

When patients are terminally ill... and we know that they're gonna die, it's always very difficult [...]. But at the same time, it's a matter of comfort... Generally, dying patients have been suffering for some time with treatment. So, I try to mentalize good things and pray to the patients when I know they are dying. I try to make [the moment of death] a peaceful moment, so that it's not so difficult, neither for me nor for the family. (E6).

Nurses realize that they need to have sensitivity to understand the way of being of each family when dealing with the imminent possibility of losing one of its members.
Each family is different. There are some cases where the family is very close, they don't leave [the patient] at all. There are other people who cannot stand seeing their loved one suffering and leave [the patient] with another person or with us. (E7)

I believe that, most of the time, [the family] is the one who most needs someone to listen to and I try to be willing to do that. (E9)

For nurses, the experience of working in the oncology area helps them to deal better with the patients' death situation, as well as the way they relate to them and their families. However, they recognize that these care situations are emotionally exhausting and, sometimes, they choose to work in areas where, according to their perception, the possibility of patient loss is relatively less.

Today it's a little easier [taking care of dying patients] than when I got here [admission to the unit] ... Today, I deal much better with this [dying] process... It's not an easy process. Currently, I work 99\% with hematology [patients], not so much with oncology [patients]. Because, for me, the emotional required for an oncology patient is much worse... So, it's a way to escape this difficult part of the area. (E4)

One of the nurses reported on the tendency of the patient with no possibility of cure to initially fight against death and the reaction of the family to this fact, when they strive to keep the patient alive or accept the dying process, adhering to palliative care.

First, a dying patient fights not to want to die. Second, the family must be consenting to a palliative care process or invest in the patient, taking him/her to an ICU, investing in all possible treatments. And third, it's a distressing process, both for the family, and much more for the patient... each one reacts in a different way: some are agonizing for a long time, others are not. (E7)

Despite the feeling of frustration and helplessness shared by the entire team for not being able to save the patient's life, nurses feel, on the other hand, satisfied to relieve the patients' suffering until the end of their life, respecting their dignity.

And, in general, everybody ends up with a negative part... as if you couldn't reverse this situation. So, it's a loss for everyone. There is only a satisfaction in the [dying] process in which you did something to alleviate their pain. Then, it brings us peace... to provide comfort in their final moments. (E7)

I think that as an oncology nurse we get this a lot, the fact of the patient living and dying with dignity. Is there a bad emotional charge? Yes, there is. But I think it's very important for the patients to have someone on their side who respects this and provides them dignity in the death process as well. (E4)

\section{Category 3: Reflecting on their experiences in the care of dying patients and their family}

When nurses report about their most remarkable experiences in caring for dying patients and their family, they point to their involvement with their patients' life story and their commitment to providing meaningful experiences for them before their death.

There was this patient who had just married. He was on his honeymoon, started to feel sick, came back and discovered the 
disease. He went for the transplant and ended up dying. So, these are always very difficult stories to deal with, and they mark us a lot. (E6)

There was a specific case, in which I became very close to this couple. The man had pancreatic cancer. I followed them for about 8 months. I tried to provide good times, such as a surprise party at the hospital. I tried to make his last few days as simple as possible. We talked a lot, I used to visit him... and it was a very peaceful death. I still talk to his wife. (E9)

Dealing with the suffering of patients and their struggle for life or doing something very important for them before they die often represents a life lesson for nurses.

I think that sometimes we say that we don't have time, that we are tired... Once, there was this patient who had meta-generalized carcinoma and she was already at the final stage... and she was waiting for her daughter to get married. She passed away at the same week her daughter got married... So, she dressed up as if she would go to the party, put on a wig, makeup... She saw her daughter's wedding on a screen... And, many times, we don't feel like going out, we don't want to enjoy life, just because we're tired. (E7)

Oh... [pause] A few years ago, I followed the disembodiment of an elderly. She had all the family and medical support. It was a peaceful process... [sighs]. The fact that marked me was the affection of all family members... without despair, just for love. (E1)

The experiences that led to a strong trust connection between the nurse and the patient show the constant suffering when dealing with the imminent possibility of death every care day and the grieving process experienced by the professional.

Two years ago, I took care of a 9-year-old child, and it was a really markable process for me, because I followed this child since the diagnosis. [...] And it marked me a lot, because I was very close to this patient. It was more than a consecutive year of treatment... If he had any procedure, if he had a puncture change [Portocath ${ }^{\oplus}$, he had to wait for me to arrive... if I was in my day off, he had to wait until the next day to be able to do it with me. And I spent a lot of bad times with him, moments when I left here, and I thought he would never come back. (E4)

I think I got really close to her, she was a patient we had... an elderly lady, and everyone was very close to her. She was hospitalized for a long time and she had a very aggressive leukemia... I was really sorry for her death, I cried a lot. It was really an impact. (E8)

\section{DISCUSSION}

From the nurses' reports, experiences and perceptions related to caring for dying cancer patients emerged. Regarding the meaning of death for these professionals, the speeches point to the influence of their beliefs, whether cultural or even religious, which lead them to consider dying as something natural, which is part of the life cycle.

Thus, death is present in our lives, for some of us earlier, for others, later. Despite this, it is seen by society as something to be avoided or postponed, as if the dying process was opposed to living ${ }^{(9-10,14)}$. Values and belief are strategies that support the coping with death by the professional. Religion makes it possible to redefine the loss, bringing it closer to the natural process of death ${ }^{(15)}$.

The death of patients can generate effects on a personal and professional level for the entire team involved in their care. It is necessary to understand the systems of meanings that influence the actions of health professionals when they deal with death, which can significantly impact the care provided at that moment ${ }^{(16)}$.

A review study that aimed to identify the coping strategies used by nursing professionals in face of the death of cancer children pointed to the fact that the actions occur influenced by the individual characteristics of the nurses, as well as by the work environment ${ }^{(17)}$.

According to the literature, among the attitudes pointed by the nurses when dealing with the death of a patient, the following stand out: the emotional support offered by other professionals and by the institution; institutional training related to the dying process and end-of-life care; the exchange of experiences among professionals working in the same professional context; the practice of sports, as well as religion and faith; and the adoption of some behaviors, such as resilience, trivialization, escape and empathy regarding death situations ${ }^{(17-18)}$

Thus, the professionals interviewed in this study showed attitudes that helped them to care for patients who were dying, such as staying close to the family, caring for patients until the end of their life with dignity and respect, maintaining a peaceful environment and leaning on their religious beliefs. These attitudes were also mentioned in previous studies ${ }^{(19)}$.

The search for spirituality and religious beliefs shows the need for help that professionals have to deal with their own conflicts and to act in order to alleviate the suffering of patients in the terminal life process ${ }^{(20)}$. Attitudes such as maintaining a peaceful environment and praying, reported by the nurses in this study, aimed to promote respect for the patient and family, but, at the same time, those are strategies to calm the internal and external discomfort of these professionals.

Nurses are the health professionals who are closest to their patients in difficult times. However, studies point to a gap in the training process, with regard to the ability to deal with death ${ }^{(17,21)}$. It is worth mentioning that, even with the experience obtained in daily living and in academic training through postgraduate courses reported by the professionals of this study, they still seem to have difficulties in dealing with death. Feelings of vulnerability and frustration generated from singular interactions established among patients, family and professionals were evident in the interviewees' speeches.

The formal training of nursing professionals with regard to death issues is something that should be explored since the undergraduate course, as dealing with death and grief is a difficult experience for students. The curricular guidelines, proposed by the Ministry of Education (MEC), highlight that this theme must be addressed from the beginning of the academic education of nurses ${ }^{(22)}$.

In this study, the nurses' speeches also showed the anguish they felt when taking care of the families of the dying patients as well. The hospitalization of a relative is a disturbing moment for family members, especially for those who maintain close emotional connections with the patients. In face of this situation, 
nurses cannot limit themselves to caring for the dying patient, since they also need to direct their actions towards the family ${ }^{(9,23)}$.

A qualitative study conducted with nurses on their experiences in caring for dying newborns and their families in the neonatal intensive care unit points that this moment is very difficult. Thus, they seek strategies to deal with suffering, expressing it through crying, when this is possible, or asking for help from other professionals, when they recognize that they do not have the emotional conditions to adequately assist the family(24).

Family plays an important role regarding the illness of its members, influencing the way patients react to this situation. In patients with no possibility of cure, family involvement is essential, and it should be included in the care process, as a way to consolidate comprehensive patient care $^{(25-26)}$.

The interviewed professionals reported on the importance of professional involvement, the connection with patients/family members and the religious belief in coping with death. These items compose the strategies used to deal with the situation and promotes intrinsic motivation, which generates a sense of competence and purpose for the profession, as well as great altruism towards others when dealing with grief ${ }^{(27)}$. However, without institutional support, these actions can generate emotional distress and suffering throughout their professional lives.

Nursing care for dying patients is permeated by norms and practices discriminated in institutional protocols, guided by ethical and legal precepts, as well as humanized care ${ }^{(28-29)}$. The institution where the study was conducted has protocols, routines and training, supported by accreditations that focus on patient and family-centered care as premises, along with the required need for professional support, made possible by groups of discussions and institutional psychological support programs, among others.

Health institutions need to adopt strategies related to providing environments and creating routines that reduce physical and emotional overload. Thus, they must offer resources that can support professionals in the development of their activities with knowledge, responsibility and resources, in addition to establishing interprofessional collaboration through palliative care protocols to help nurses to experience life-related experiences in a less traumatic way ${ }^{(30)}$.

\section{Limitations of the study}

It is recommended to carry out new studies that can expand knowledge on the topic. Thus, including the approach of professionals with different profiles or categories, or even in different contexts, such as public hospitals, home care services or pediatric units, can expand the understanding of the experience of dealing with death in care of patients and their family.

\section{Contributions to the area of nursing}

The results found in this study will possibly help to subsidize issues related to the education and training of nurses who deal with dying patients. They also point to the need to establish intervention programs to prevent the burnout of professionals working in oncology, also considering the need for health institutions to commit to this topic.

\section{FINAL CONSIDERATIONS}

This study made it possible to know the perceptions and experiences of nurses who care for dying cancer patients, showing their involvement in this situation, as well as the anxiety and anguish faced by these professionals.

For the interviewees, dealing with death is hard, a painful phenomenon and difficult to accept, especially when it comes to oncology. Bringing the multidisciplinary team closer to this topic, leading its members to reflect on death and its meanings becomes imperative, aiming to alleviate the professionals' suffering when facing this situation.

The results of this study show the importance of a qualitative approach for investigations like this, in which complicated situations such as death are contemplated in the health area. Working with people's perceptions, experiences and feelings requires the researchers' preparation, who finds qualitative research as a support for their concerns.

\section{REFERENCES}

1. Ministério da Saúde (BR). Instituto Nacional do Câncer José Alencar Gomes da Silva. Câncer: o que é cancer. [Internet]. Rio de Janeiro: INCA; 2019 [cited 2020 Mar 25]. Available from: https://www.inca.gov.br/o-que-e-cancer

2. Union for International Cancer Control. New global cancer data suggests that the global cancer burden has risen to 18.1 million cases and 9.6 million cancer deaths 2018 [Internet]. Geneva: Switzerland; 2018 [cited 2019 Jan 05]. Available from: https://www.uicc.org/ new-global-cancer-data-globocan-2018

3. Ministério da Saúde (BR). Instituto Nacional do Câncer José Alencar Gomes da Silva. Estimativa 2018: incidência de câncer no Brasil [Internet]. Rio de Janeiro: INCA; 2017 [cited 2019 Jan 18]. Available from: http://www1.inca.gov.br/rbc/n_64/v01/pdf/15-resenha-estimativa2018-incidencia-de-cancer-no-brasil.pdf

4. Freire ME, Costa SF, Lima RA, Sawada NO. Health-related quality of life of patients with cancer in palliative care. Texto Contexto Enferm. 2018;27(2):1-13. doi:10.1590/0104-070720180005420016

5. Vasques TC, Lunardi LV, Arruda da Silva P, Carvalho KK, Lunardi Filho WD; Barros EJ. Perception of nursing professionals about patient care of the terminally in the hospital environment. Texto Contexto Enferm. 2016;25(3):2-7. doi: 10.1590/0104-07072016000480014

6. Dong F, Zheng R, Chen X, Wang Y, Zhou H, Sun R. Caring for dying cancer patients in the Chinese cultural context: a qualitative study from the perspectives of physicians and nurses. Eur J Oncol Nurs. 2016; 21:189-96. doi: 10.1016/j.ejon.2015.10.003 
7. Cruz FS, Rossato LG. Care given to cancer patients undergoing chemotherapy: knowledge of family health strategy nurses. Rev Bras Cancerol [Internet]. 2015 [cited 2019 Dec 17];61(4):335-41. Available from: http://www1.inca.gov.br/rbc/n_61/v04/pdf/04-artigo-cuidadoscom-o-paciente-oncologico-em-tratamento-quimioterapico-o-conhecimento-dos-enfermeiros-da-estrategia-saude-da-familia.pdf

8. Theobald MR, Santos ML, Andrade SM, Carli AD. Percepções do paciente oncológico sobre o cuidado. Physis. 2016;26(4):1249-69. doi: $10.1590 / \mathrm{s} 0103-73312016000400010$

9. Luz KR, Vargas MA, Barlem EL, Schmitt PH, Ramos FR, Meirelles BH. Coping strategies for oncology nurses in high complexity. Rev Bras Enferm. 2016;69(1):59-63. doi: 10.1590/0034-7167.2016690109i

10. Bastos RA, Quintana AM, Carnevale F. Psychological distress experienced by nurses who work with patients in death process: a clinicalqualitative study. Trends Psychol. 2018 26(2):795-805. doi: 10.9788/tp2018.2-10pt

11. Ministério da Saúde (BR). Conselho Nacional em Saúde. Resolução n.466, de 12 de dezembro de 2012. Aprova as diretrizes e normas regulamentadoras de pesquisas envolvendo seres humanos [Internet]. Diário Oficial da União, Brasília (DF): 2012 [cited 2019 Dec 17] Dez 12. Available from: https://bvsms.saude.gov.br/bvs/saudelegis/cns/2013/res0466_12_12_2012.html

12. Tong A, Sainsbury P, Craig J. Consolidated criteria for reporting qualitative researchttps://bvsms.saude.gov.br/bvs/saudelegis/cns/2013/ res0466_12_12_2012.htmlh (COREQ): a 32-item checklist for interviews and focus groups. Int J Qual Health Care. 2007;19(6):349-57. doi: 10.1093/intqhc/mzm042

13. Bardin L. Análise de conteúdo. 7a ed. Lisboa: Edições 70; 2011.

14. D’Agostini CL, Casagrande SL. Percepção da morte na visão do idoso. Psicol Pesq [Internet]. 2015 [cited 2019 Mar 21];173-85. Available from: https://portalperiodicos.unoesc.edu.br/pp_ae/article/view/8701/4955

15. Silva IN, Salim NR, Szylit R, Sampaio PS, Ichikawa CR, Santos MR. Knowing nursing team care practices in relation to newborns in end-of-life situations. Esc Anna Nery. 2017;21(4):e20160369. doi: 10.1590/2177-9465-ean-2016-0369

16. Prado RT, Leite JL, Castro EA, Silva LJ, Silva IR. Uncovering care for patients in the death/dying process and their families. Rev Gaucha Enferm. 2018;39:e20170111. doi: 10.1590/1983-1447.2018.2017-0111

17. Macedo A, Mercês NNA, Silva LAGP, Sousa GCC. Nurses' coping strategies in pediatric oncology: an integrative review. Rev Pesqui: Cuid Fundam. 2019;11(3):718-24. doi: 10.9789/2175-5361.2019. v11i3.718-724 21

18. Mons SC, Pereira GS, Lima LLM, Leite CL, Fernandes RTP. Estratégias de defesa no processo de morte e morrer: um desafio aos profissionais da enfermagem. Res, Soc Develop. 2020;9(2):e190922139.

19. Rosa DS, Couto SA. The coping emotional professional nursing in patient care in the process of life terminality. Rev Enferm Contemp. 2015;4(1):92-104. doi: 10.17267\%252F2317-3378rec.v4i1.467

20. Sampaio AD, Siqueira HC. Spirituality influence in the treatment of oncological user: nursing view. Cienc Cienc Biol Agrar Saúd [Internet]. 2016 [cited 2019 Dec 17];20(3):153-60. Available from: https://revista.pgsskroton.com/index.php/ensaioeciencia/article/view/4433/3473

21. Nunes EC, Santos AA. Challenges of nursing teaching learning to care for human dying - professors' perceptions. Esc Anna Nery. 2017;21(4):e20170091. doi: 10.1590/2177-9465-ean-2017-0091

22. Ministério da Educação (BR). Conselho Nacional de Educação. Diretrizes curriculares nacionais dos cursos de graduação de enfermagem, medicina e nutrição [Internet]. Ministério da Educação; 2001 [cited 2019 Mar 21]. Available from: http://portal.mec.gov.br/dmdocuments/ces1133.pdf

23. Silva AA, Sanchez GM, Mambrini NS, Ziebell de Oliveira M. Predictor variables for burnout among nursing professionals. Rev Psicol[Internet]. 2019[cited a2019 Dec 17];37(1):319-48. Available from: https://dialnet.unirioja.es/servlet/articulo?codigo=6720813

24. Almeida FA, Moraes MS, Cunha ML. Taking care of the newborn dying and their families: Nurses' experiences of neonatal intensive care. Rev Esc Enferm USP. 2016;50(spe Spec):122-9. doi: 10.1590/S0080-623420160000300018

25. Menin GE, Pettenon MK. Terminally child life: perceptions and feelings of nurses. Rev Bioet. 2015;23(3):608-4. doi: 10.1590/1983-80422015233097

26. Paula DP, Silva GR, Andrade JM, Paraiso AF. Cancer in children and adolescents in the family settings: perceptions and experiences with respect to their diagnosis. Rev Cuid. 2019;10(1):1-12. doi: 10.15649/cuidarte.v10i1.570

27. Almeida FA, Funes MM, Moraes MW. A Vivência do enfermeiro no processo de morte e morrer do paciente com câncer [Internet]. In: Atas do $7{ }^{\circ}$ Congresso Ibero-Americano em Investigação Qualitativa; 2018 Jul 10-13; CIAIQ; 2018 [cited 2019 Mar 21]. Available from: https:// proceedings.ciaiq.org/index.php/ciaiq2018/article/view/1946

28. Prado RT, Leite JL, Silva IR, Silva LJ, Castro EAB. Processo de morte/morrer: condições intervenientes para o gerenciamento do cuidado de enfermagem. Rev Bras Enferm. 2018;71(4):2121-9. doi: 10.1590/0034-7167-2017-0173

29. Coutinho JF, Cruz IC. The care of the body after death in the intensive care unit: systematic literature review. Journal of Specialized Nursing Care [Internet]. 2018 [cited 2019 Mar 21];10(1): Available from: http://www.jsncare.uff.br/index.php/jsncare/article/view/2995/764

30. Souza PS, Conceição AO. Process of dying in a pediatric intensive therapy unit. Rev Bioét. 2018;26(1):127-34. doi: $10.1590 / 1983-80422018261234$ 